\title{
Myogenin resides in the nucleus and acquires high affinity for a conserved enhancer element on heterodimerization
}

\author{
Thomas J. Brennan and Eric N. Olson ${ }^{1}$ \\ Department of Biochemistry and Molecular Biology, The University of Texas, MD Anderson Cancer Center, Houston, Texas \\ 77030 USA
}

\begin{abstract}
Myogenin is a member of a family of muscle-specific factors that can activate the muscle differentiation program in nonmyogenic cells. Using antibodies directed against unique domains of myogenin, we show in the present study that myogenin resides in the nucleus of differentiated muscle cells. Myogenin translated in vitro does not exhibit detectable DNA binding activity; however, when dimerized with the ubiquitous enhancerbinding factor E12, it acquires high affinity for an element in the core of the muscle creatine kinase (MCK) enhancer that is conserved among many muscle-specific genes. Antibody disruption experiments show that myogenin, synthesized during differentiation of the $\mathrm{BC}_{3} \mathrm{H} 1$ and $\mathrm{C} 2$ muscle cell lines, is part of a complex that binds to the same site in the MCK enhancer as myogenin-E12 translated in vitro. Mutagenesis of the myogenin-E12-binding site in the MCK enhancer abolishes binding of the heterodimer and prevents transactivation of the enhancer by myogenin. The properties of myogenin suggest that it functions as a sequencespecific DNA-binding factor that interacts directly with muscle-specific genes during myogenesis. The dependence of myogenin on E12 for high-affinity DNA binding activity also suggests that the susceptibility of various cell types to the actions of myogenin may be influenced by the cellular factors with which it may interact.
\end{abstract}

[Key Words: Myogenin; enhancer-binding factor E12; DNA-binding factors; MCK enhancer; muscle-specific genes]

Received December 28, 1989; revised version accepted February 7, 1990

Establishment of a fully differentiated skeletal muscle phenotype involves the expression of a battery of muscle-specific genes that encode proteins required for the specialized functions of the mature myofiber. The cell-type-specificity and developmental regulation of this broad array of unlinked genes suggest the existence of a regulatory program that coordinately controls gene expression in developing muscle cells. Numerous studies have described cis-regulatory sequences that confer appropriate regulation on muscle-specific genes. In many cases, these elements have been found to be conserved among multiple muscle-specific genes and to serve as binding sites for putative nuclear regulatory factors (for review, see Rosenthal 1989). The precise specificity of expression of muscle-specific genes can be envisioned to be mediated by one or more muscle-specific transcription factors, by interactions between muscle-specific regulatory factors and general transcription factors, or by combinations of ubiquitous factors. Alternatively, negative regulatory factors could influence the expression of muscle-specific genes by ensuring that they are not expressed at inappropriate times during

${ }^{1}$ Corresponding author. development or in inappropriate cell types. Indeed, evidence has been obtained for each kind of mechanism in the control of gene expression during myogenesis.

Recent studies have demonstrated the existence of a family of regulatory factors-myd (Pinney et al. 1988), MyoD1 (Davis et al. 1987), myogenin (Edmondson and Olson 1989; Wright et al. 1989), Myf-5 (Braun et al. 1989a), and MRF-4 (Rhodes and Konieczny 1989)-that are able to convert the multipotential mesodermal stem cell line $10 \mathrm{~T}^{1 / 2}$ to the myogenic lineage. MyoD1, myogenin, Myf-5, and MRF-4 have been isolated as cDNAs and have been shown to be expressed exclusively in skeletal muscle (Davis et al. 1987; Braun et al. 1989a Edmondson and Olson 1989; Rhodes and Konieczny 1989; Wright et al. 1989). In addition to activating the expression of genes associated with myogenesis, these regulatory factors positively autoregulate their own expression and activate one another's expression (Braun et al. 1989b; Thayer et al. 1989; Brennan et al. 1990). It has, therefore, not yet been established unequivocally whether each factor can regulate muscle-specific genes independently or whether one factor mediates the actions of the others. The individual roles of myogenin MyoD1, and Myf-5 in the control of myogenesis are complicated further by the fact that many muscle cell 
lines express only a subset of these factors (Davis et al. 1987; Braun et al. 1989b; Edmondson and Olson 1989).

Myogenin, MyoD1, Myf-5, and MRF-4 show extensive homology within a basic region and a conserved helixloop-helix motif (Murre et al. 1989a,b). A similar domain is found in two immunoglobulin enhancer-binding gene products, E12 and E47, which appear to be expressed ubiquitously (Murre et al. 1989a), in several regulatory factors from Drosophila that control cell determination, including achaete scute (Villares and Cabrera 1987; Alonso and Cabrera 1988), daughterless (Caudy et al. 1988; Cronmiller et al. 1988), twist (Thisse et al. 1988), enhancer of split (Klaembt et al. 1989), and hairy (Rushlow et al. 1989), in the lyl-1 gene product (Mellentin et al. 1989|, and in members of the myc family of oncogenes (Battey et al. 1983; DePinho et al. 1986). The helix-loop-helix domain has been shown recently to mediate heterodimerization between either the daughterless gene product, E12, or $\mathrm{E} 47$ and the achaete scute gene product or MyoDl (Murre et al. 1989b). The helixloop-helix domain and adjacent basic region of MyoDl is necessary and sufficient for myogenic conversion (Tapscott et al. 1988) and for binding of MyoDl to the MCK enhancer (Lassar et al. 1989), which confers skeletal muscle-specific expression (Jaynes et al. 1988; Sternberg et al. 1988, 1989).

Despite the structural and functional similarities between myogenin, MyoDl, and Myf-5, there is increasing evidence that these factors do not function identically. The genes are expressed, for example, at different times during embryonic development in vivo (Sassoon et al. 1989), and during myogenesis of established muscle cell lines in vitro. In particular, MyoDl and Myf-5 are expressed in several muscle cell lines prior to differentiation (Braun et al. 1989a; Davis et al. 1987), whereas myogenin is expressed only after withdrawal of mitogens from myoblasts (Edmondson and Olson 1989; Wright et al. 1989|. Paradoxically, myogenin is also expressed in embryonic somites prior to the expression of MyoD1 or other muscle-specific genes (Sassoon et al. 1989|. On the basis of these unique patterns of expression, it is reasonable to expect that the functions of myogenin and MyoD1 are not entirely redundant and that they may modulate the expression of different genes through interaction with different cellular factors and regulatory elements. In this regard, muscle-specific expression of the gene encoding the $\delta$ subunit of the acetylcholine receptor has been shown recently to be mediated by a DNA element that does not contain a binding site for MyoDl (Baldwin and Burden 1989), indicating that other factors are necessary for manifestation of the complete myogenic phenotype.

To define further the functional relationships between the different myogenic regulatory factors, we prepared antisera against synthetic peptides corresponding to segments of myogenin that lie outside of the region conserved between myogenin, MyoDl, and Myf-5. By use of these antibodies in this study, we show that myogenin exists in the nucleus and acquires high affinity for a single site in the MCK enhancer on dimerization with the helix-loop-helix protein E12. The myogenin-E12binding site is essential for high-level, muscle-specific activity and for myogen-independent regulation of the MCK enhancer. Antibody disruption experiments show that myogenin, synthesized during differentiation of the $\mathrm{BC}_{3} \mathrm{Hl}$ and $\mathrm{C} 2$ muscle cell lines, is part of a complex that binds to the same site in the MCK enhancer as myogenin-E12 synthesized in vitro. These results suggest that myogenin regulates myogenesis through its interactions with regulatory elements associated with muscle-specific genes. The dependence of myogenin on E12 for sequence-specific DNA binding also indicates that myogenin acts in concert with other cellular factors to regulate muscle-specific gene expression and suggests that the susceptibility of various cell types to its actions are dictated by the repertoire of factors with which myogenin can interact.

\section{Results}

Myogenin is localized to the nucleus

The mouse myogenin cDNA contains a major uninterrupted open reading frame with the potential to encode a polypeptide with a predicted molecular mass of $25.2 \mathrm{kD}$ (Edmondson and Olson 1989). The region between amino acids 63 and 136 of the predicted myogenin polypeptide shows $80 \%$ homology to the basic myc domain of MyoDl that has been shown to be necessary and sufficient for myogenic conversion (Tapscott et al. 1988) and $75 \%$ homology to the corresponding region of human Myf-5 (Braun et al. 1989a). To obtain antisera specific for myogenin that would not cross-react with MyoD1 or Myf-5, we immunized rabbits with two 15amino-acid synthetic peptides corresponding to regions of myogenin outside of the MyoD1/Myf5 homology domain (see Materials and methods).

Antipeptide antisera were tested initially by Western blot analysis and reacted specifically with myogenin produced in bacteria (data not shown). The antipeptide antisera also specifically immunoprecipitated in vitrotranslated myogenin, which was effectively decreased by competition with an excess of the immunogenic peptides (data not shown).

Our initial interest was to determine the subcellular location of myogenin by indirect immunofluorescence. Figure 1 shows that myogenin was localized to the nuclei of C2 myotubes. Weak staining was also detectable in the cytoplasm of myotubes, which may represent newly synthesized protein en route to the nucleus. Staining of $10 \mathrm{~T}^{1 / 2}$ cells and undifferentiated myoblasts with the antimyogenin antisera did not result in detectable immunofluorescence (data not shown).

Myogenin gene expression was also examined by immunoprecipitation from extracts of metabolically labeled $\mathrm{C} 2$ cells. The antimyogenin antisera specifically recognized a protein with an apparent molecular mass of $32 \mathrm{kD}$ in nuclear extracts from $\left[{ }^{35} \mathrm{~S}\right]$ methionine-labeled C2 myotubes (Fig. 2). Prolonged exposure to film also revealed a species with a molecular mass of $34 \mathrm{kD}$ that 

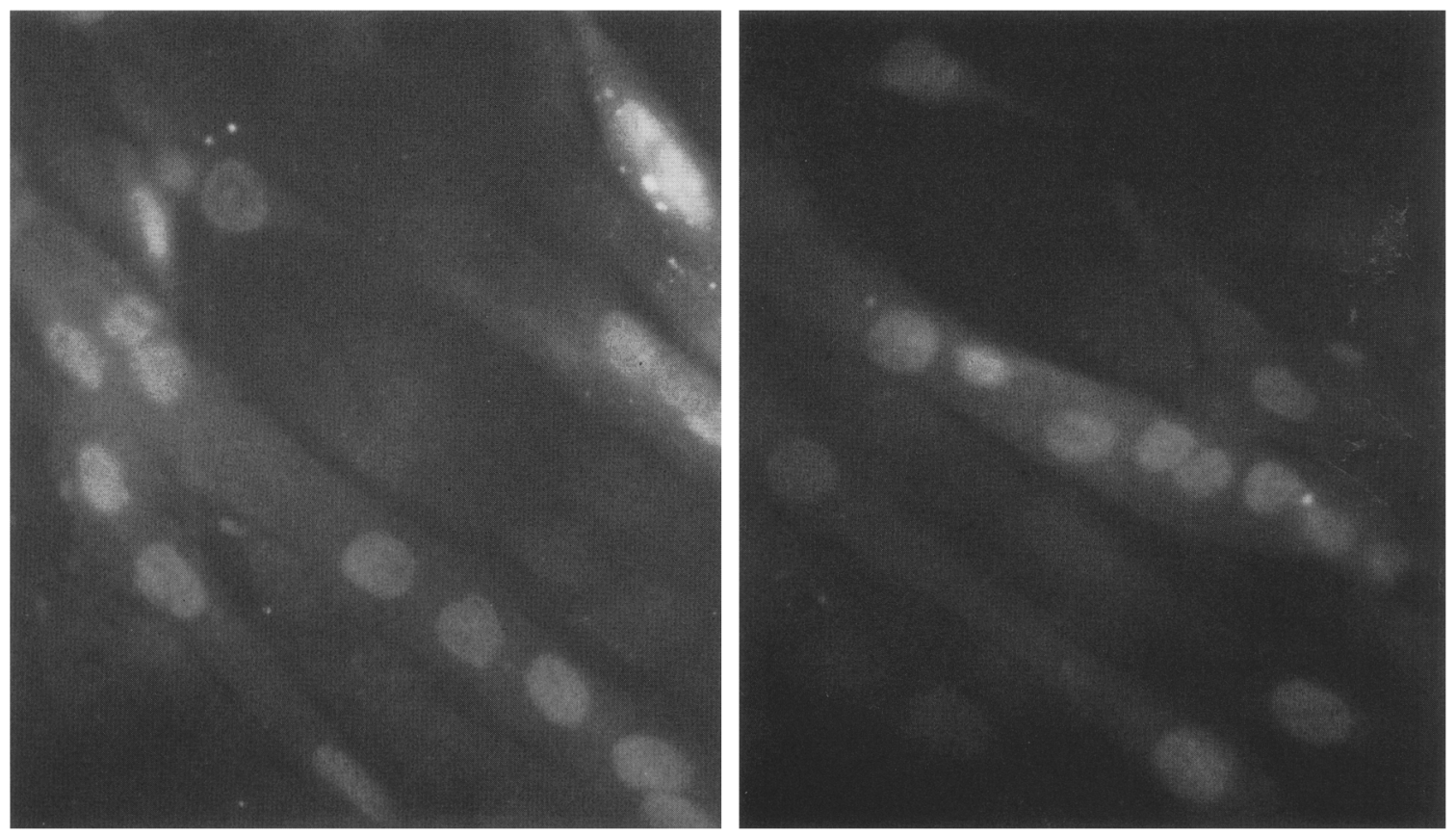

Figure 1. Immunofluorescent localization of myogenin to the nucleus of differentiated $\mathrm{C} 2$ myotubes. $\mathrm{C} 2$ myotubes were fixed and analyzed for myogenin by indirect immunofluorescence as described in the text. Two representative fields of view are shown.

was specifically immunoprecipitated by the antisera. The identity of these proteins as myogenin was confirmed by the ability of the unlabeled myogenin peptides to compete for immunoprecipitation by the antisera. Extracts from $10 \mathrm{~T}^{1 / 2}$ cells (Fig. 2) and C2 myoblasts (data not shown/ did not contain proteins that were recognized specifically by the antimyogenin antisera. We do not yet know why myogenin migrates as a doublet, but it may reflect differences in the extent of phosphorylation, as the larger species is phosphorylated to a higher stoichiometry than the lower one (T.J. Brennan and E.N. Olson, unpubl.).

Myogenin binds to the MCK enhancer as a heterooligomer with the ubiquitous helix-loop-helix protein E12

We reported previously that myogenin activates the MCK enhancer in transfected 10T $1 / 2$ cells (Edmondson and Olson 1989). It was unclear, however, whether the effects of myogenin on the enhancer were direct or were mediated by other myogenic regulatory factors such as MyoDl, which is expressed in myogenin-transfected 10T1/2 cells (Thayer et al. 1989; Brennan et al. 1990). To determine whether myogenin interacts directly with the MCK enhancer, we initially examined whether a $\beta$-galactosidase-myogenin or TrpE-myogenin fusion protein from bacterial lysates would bind to the MCK enhancer in gel retardation assays. Although weak binding was detectable, the affinity of the fusion proteins was relatively low (T.J. Brennan and E.N. Olson, unpubl.).

During the course of these studies, Murre et al. (1989a,b) reported that MyoD1 forms a heterodimer with the immunoglobulin enhancer-binding factor E12 and that this heterodimer shows high affinity for the $\mathrm{kE} 2$ motif (or E-box), which is contained within the immunoglobulin $\kappa$ and heavy-chain enhancers /Church et al.

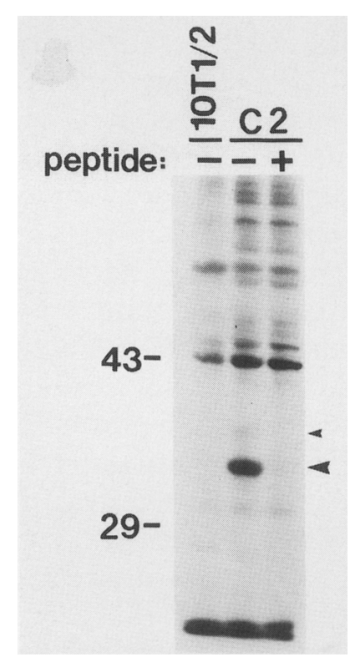

Figure 2. Immunoprecipitation of myogenin from nuclear extracts from $\mathrm{C} 2$ and $10 \mathrm{~T}^{1 / 2}$ cells. $\mathrm{C} 2$ myotubes and $10 \mathrm{~T}^{1 / 2}$ cells were labeled with $\left[{ }^{35} \mathrm{~S}\right] \mathrm{methionine}$ for $5 \mathrm{hr}$ as described in the text. Nuclear extracts were then prepared and equivalent amounts of radioactivity from each extract were immunoprecipitated with the antimyogenin antisera in the presence $(+)$ or absence $(-)$ of unlabeled myogenin peptides. Proteins migrating above $42 \mathrm{kD}$ are nonspecific. Exposure time was 5 days. Large and small arrowheads denote the major and minor forms, respectively, of myogenin. They are present only in C2 myotubes and are competed by unlabeled myogenin peptides. 
1985; Ephrussi et al. 1985; Sen and Baltimore 1986; Lenardo et al. 1987) and which resembles two elements within the core of the MCK enhancer (Jaynes et al. 1988; Sternberg et al. 1988). To ascertain whether myogenin shared this property with MyoD1, myogenin and E12 were prepared by in vitro translation of the corresponding RNAs in a rabbit reticulocyte lysate. The in vitro translation products were then incubated with a 32P-labeled DNA fragment that encompassed 68 bp (between -1204 and -1137 , see below, Fig. 7) of the MCK enhancer core. As shown in Figure 3 (lane 2), myogenin showed no detectable binding to the MCK enhancer in the gel mobility-shift assay. E12 alone also did not show significant binding to the enhancer (lane 3), although more recently we have detected a low level of binding of E12 under slightly different assay conditions (data not shown). When mRNAs encoding myogenin and E12 were translated together, however, they gave rise to a specific mobility-shifted complex with the enhancer (Fig. 3A, lane 4). Competition experiments with a va- riety of homologous and heterologous DNAs showed that binding of myogenin-E12 to the enhancer core was sequence specific (see below). The presence of myogenin in this DNA-protein complex was confirmed by the ability of antimyogenin antibody to abolish its formation (Fig. 3A, lane 6). In contrast, preimmune rabbit serum had no effect on generation of the myogeninE12-dependent complex (Fig. 3A, lane 7). Together, these results show that the affinity of myogenin alone for the MCK enhancer is low, but that, in the presence of E12, myogenin acquires the ability to bind with high affinity to the MCK enhancer core. On the basis of the intensity of the myogenin-E12-dependent complex and the relative inefficiency of heterodimerization (see below), we estimate that the affinity of myogenin-E12 for the MCK enhancer core is at least 100 -fold higher than the affinity of myogenin alone.

To confirm that myogenin and E12 formed a heterodimer and to determine whether dimerization between these proteins required DNA, the two mRNAs were co-
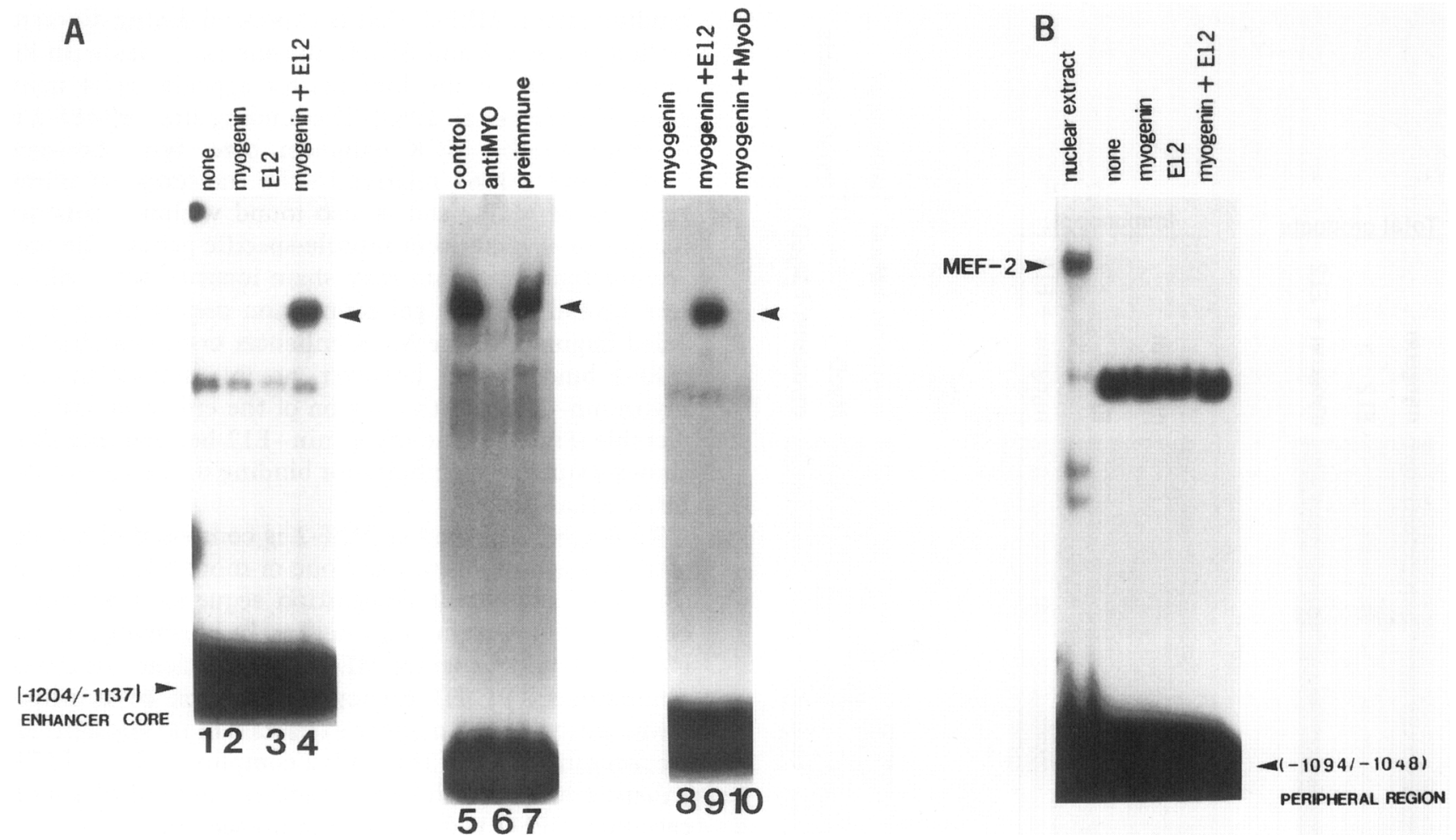

Figure 3. Gel mobility-shift assays using fragments of the MCK enhancer and in vitro-translation products of myogenin, MyoDl, and E12. mRNAs for the indicated proteins were translated in vitro and translation products were incubated with the indicated ${ }^{32} \mathrm{P}-$ labeled DNA fragments from the MCK enhancer. DNA-protein complexes were resolved on native acrylamide gels as described in the text. (A) In vitro-translation products of myogenin, E12, and $\mathrm{MyoDl}$, as indicated, were incubated with a ${ }^{32} \mathrm{P}-\mathrm{labeled}$ DNA probe corresponding to the MCK enhancer core $(-1204 /-1137)$. The middle panel of $A$ shows a gel retardation assay with myogenin plus E12 in the absence (control, lane 5) and presence of antimyogenin antibodies (antiMYO, lane 6) or preimmune rabbit serum (preimmune, lane 7). The specific DNA-protein complex generated with myogenin-E12 is denoted with an arrow. In the right panel of $A$, myogenin (lane 8), myogenin plus E12 (lane 9), and myogenin plus MyoDl (lane 10) were translated in vitro and the translation products were incubated with the enhancer core. $(B)$ In vitro-translation products for myogenin and E12 were incubated with a ${ }^{32} \mathrm{P}-1$ abeled probe corresponding to a peripheral region of the MCK enhancer $(-1094 /-1048)$, which contains the binding site for MEF-2. Nuclear extract refers to a gel retardation assay performed with nuclear extract from differentiated $\mathrm{BC}_{3} \mathrm{H} 1$ cells. The position of the MEF- 2 complex is indicated. "None" in $A$ and $B$ refers to reticulocyte lysate alone without translation of exogenous mRNAs. 
translated in vitro and immunoprecipitated with the antimyogenin antisera. As shown in Figure 4 (lane 6), E12 precipitated with myogenin when the two mRNAs were translated together, but not when it was translated alone (lane 5). These results demonstrate that myogenin and E12 form a stable complex in vitro and that association of these factors occurs in the absence of DNA. Heterodimerization also occurs when myogenin and E12 are translated separately and combined subsequently (data not shown). Although E12 and myogenin were present in approximately equal amounts in the immunoprecipitation reactions (Fig. 4, lanes $1-3$ ), only about $10 \%$ of the E12 translation product was precipitated by the antimyogenin antibody (lane 6), suggesting that heterodimerization in vitro is relatively inefficient. On the basis of the behavior of E12 and E47 (Murre et al. 1989a,b), we interpret these results to indicate that E12 and myogenin heterodimerize. It is possible, however, that higher order oligomers could be formed, as well.

We also examined whether myogenin would acquire the ability to bind to the MCK enhancer in the presence of MyoDl, but observed no DNA binding when myo-

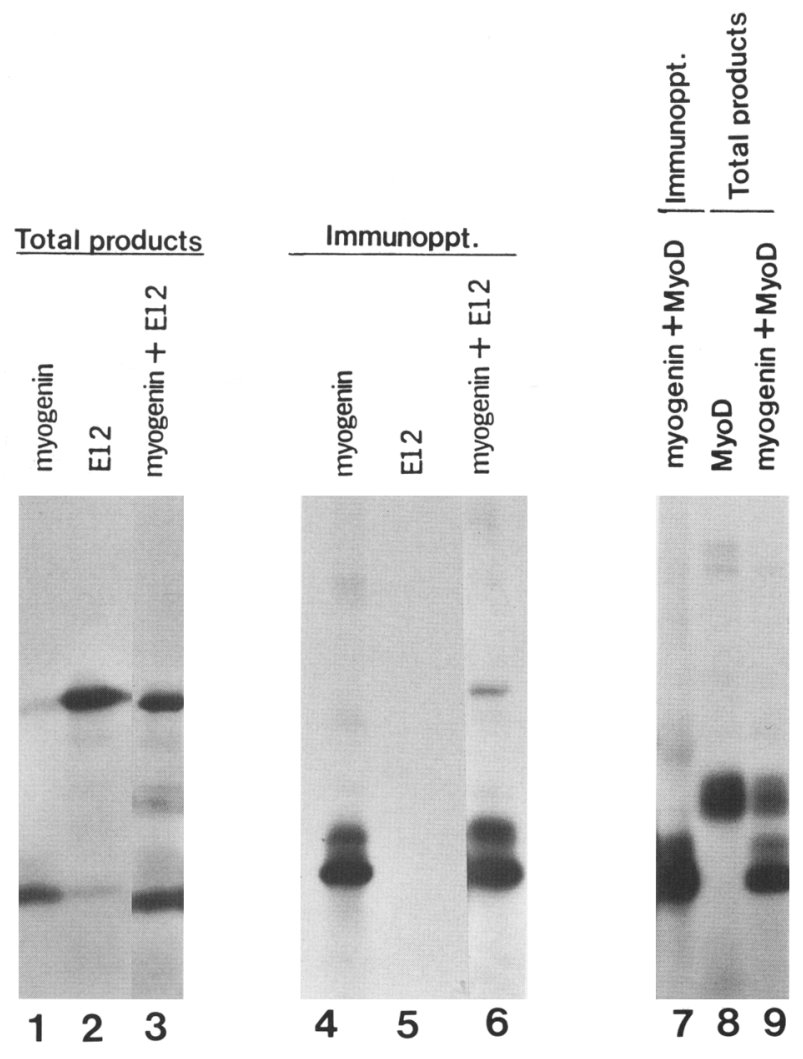

Figure 4. In vitro translation of myogenin, MyoDl, and E12 and coimmunoprecipitation of E12 with myogenin. mRNAs for the indicated proteins were translated in vitro and aliquots of translation reactions (lanes $1-3,8,9$ ) were applied directly to an SDS-polyacrylamide gel (total products) or were immunoprecipitated (lanes 4-7) with antibodies against myogenin (Immunoppt.). Following electrophoresis, gels were processed for fluorography. The position of E12, which coimmunoprecipitates with myogenin, is indicated with an arrowhead (center panel). genin and MyoDl were translated together (Fig. 3A, lane 10). Moreover, in contrast to the ability of bacterially expressed MyoDl to bind to the MCK enhancer (Lassar et al. 1989), in vitro-translated MyoDl did not show significant binding to the enhancer under the conditions of these assays (Fig. 3A, lane 10). Cotranslation of myogenin and $\mathrm{MyoD1}$, followed by immunoprecipitation, also failed to show heterodimerization between myogenin with MyoD1 (Fig. 4, right panel, lanes 7-9). We estimate that the sensitivity of these assays is such that we would be able to detect heterodimerization between myogenin and MyoDl if it occurred with an efficiency of about $10 \%$ the efficiency of heterodimerization between myogenin and E12. We also searched for potential interactions between myogenin and USF, a helix-loop-helix protein that is expressed in a wide range of cell types; no interactions between these proteins were detected (T.J. Brennan, M. Sawadogo and E.N. Olson, unpubl.).

\section{Myogenin is distinct from MEF-2}

We recently identified a muscle-specific enhancerbinding factor, MEF-2, that is expressed during differentiation of the $\mathrm{C} 2$ and $\mathrm{BC}_{3} \mathrm{Hl}$ muscle cell lines with kinetics similar to the kinetics for appearance of myogenin (Gossett et al. 1989). The binding site for MEF-2 is adjacent to the MCK enhancer core, lying between -1077 and -1062 relative to the transcription initiation site of MCK, and is also found within regulatory regions of several other muscle-specific genes. The possibility that myogenin may share identity with MEF-2 was investigated by gel retardation assays using a labeled fragment of the MCK enhancer encompassing the MEF-2 binding site; however, no interaction between myogenin-E12 and this region of the enhancer was detectable (Fig. 3B). The myogenin-E12 heterodimer thus shows sequence specificity for binding to the core of the MCK enhancer.

To determine whether MEF-2 is composed of a complex between myogenin and one or more other proteins that have a different recognition sequence from myogenin-E12, we examined whether the antimyogenin antibodies would recognize MEF-2 from nuclear extracts of differentiated $\mathrm{BC}_{3} \mathrm{Hl}$ myocytes. Addition of antimyogenin antibodies to nuclear extracts had no apparent effect on generation of the MEF-2 complex with the MCK enhancer (data not shown). Together, these results indicate that MEF-2 is distinct from myogenin.

Identification of the binding site for the myogenin-E12 heterodimer

The recognition sequence within the MCK enhancer for the myogenin-E12 heterodimer was determined by methylation interference. As shown in Figure 5, methylation of two guanines on the coding strand and four guanines on the noncoding strand strongly interfered with binding of the heterodimer to the MCK enhancer. 
The contact points for the myogenin-E12 heterodimer on the MCK enhancer correspond to the downstream кE2-like motif (or E-box), which has been referred to as the right MyoDl-binding site by Lassar et al. (1989). The most upstream guanine on the coding strand of this E-box (nucleotide - 1146) corresponds to the nucleotide that was shown to interact with bacterially expressed MyoDl (Lassar et al. 1989). Methylation of the guanine at -1143 on the coding strand did not affect binding of MyoD1, but partially interfered with binding of myogenin-E12. On the noncoding strand, methylation of guanines at $-1151,-1149,-1148$, and -1145 interfered with binding of myogenin-E12. Of these, only guanines -1151 and -1145 interfered with binding of bacterial MyoD1 (Lassar et al. 1989). Thus, the myogenin-E12 heterodimer binds to the same region of the MCK enhancer as MyoD1, but shows a unique set of guanine contact points. The contact points for MyoDl$\mathrm{E} 12$ or MyoD1-E47 heterodimers have not yet been reported.

It should be pointed out that an additional E-box with similarity to the $\mathrm{KE} 2$ motif has been identified in the MCK enhancer 20 nucleotides upstream of the myogenin-E12-binding site (Jaynes et al. 1988; Sternberg et al. 1988). A stretch of $10 \mathrm{~d}(\mathrm{C}-\mathrm{G})$ residues that does not appear to be required for binding lies between the two sites (see below, Fig. 7A). MyoD1 has been shown to exhibit low affinity for this upstream E-box, which has been referred to as the left MyoD1-binding site (Lassar et al. 1989). We did not detect any interaction, however, between the myogenin-E12 heterodimer and this region of the enhancer, referred to as E-box $\mathrm{L}_{\mathrm{L}}$ (Fig. 5 and see below!.

To investigate whether the $\mathrm{kE2}$-like motif in the MCK enhancer was sufficient for binding of myogenin-E12, we examined binding of the heterodimer to an oligomer corresponding to this site. As shown in Figure 6A, myogenin-E12 gave rise to a specific DNA-protein complex with the MCK oligomer, indicating that sequences surrounding this motif in the complete enhancer are not required for binding. Binding of myogenin-El2 to the labeled oligomer was inhibited by the corresponding unlabeled oligomer, but was not by an oligomer encompassing the upstream $\kappa E 2$ site (Fig $6 \mathrm{~B}$ ). These results confirm the methylation interference data and indicate that myogenin-E12 is specific for the downstream $\mathrm{kE2}$ site. Gel retardation assays with a labeled oligomer corresponding to the upstream $\mathrm{KE} 2$ motif also failed to reveal binding of myogenin-E12 (data not shown).

\section{Mutagenesis of the myogenin-E12 binding site abolishes binding of myogenin-E12 and prevents activation of the MCK enhancer by myogenin}

To define further the binding site for myogenin-E12 within the MCK enhancer, we created a site-specific mutation at the site that was shown by methylation interference to bind the heterodimer (Fig. 7A). By use of a 179-bp fragment of the mutant enhancer encompassing

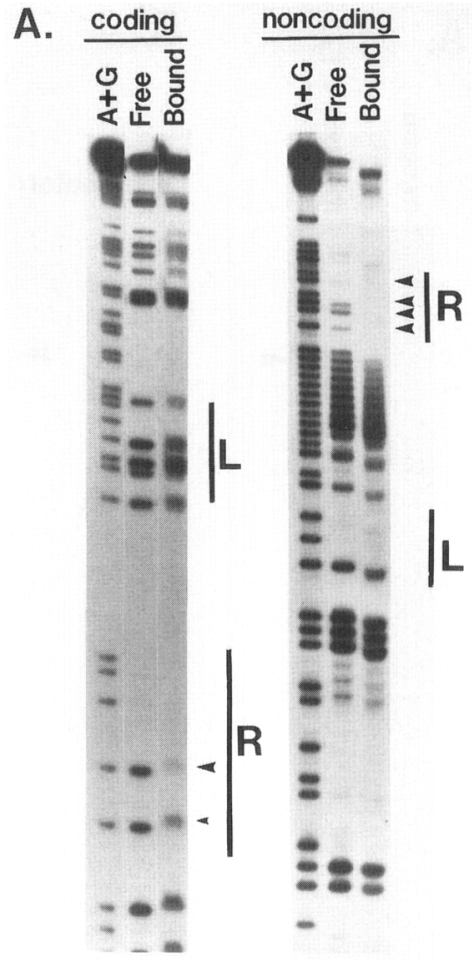

B.

$-1154$

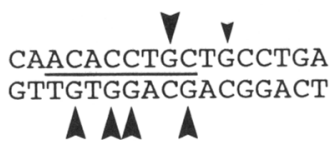

$-1138$

Figure 5. Methylation interference of myogenin-E12 heterodimer on the MCK enhancer. mRNAs for myogenin and E12 were cotranslated in vitro and used in gel retardation assays with a fragment of the MCK enhancer encompassing the region between -1204 and -1137 bp relative to the transcription initiation site. The DNA probe was partially methylated and was labeled on either the coding or noncoding strand as described in the text. Following separation of bound and free DNA on a nondenaturing gel, the corresponding regions of the gel were excised, DNA was isolated, cleaved at modified guanines, and separated on a sequencing gel. $(A) \mathrm{A}+\mathrm{G}$ reactions (Maxam and Gilbert 1980) for both strands are shown. Methylated guanines that interfere with binding of myogenin-E12 are indicated with arrows. The small arrow on the coding strand denotes partial interference. Locations of the right $(R)$ and left $(L)$ E-boxes are shown (see text for details). (B) Nucleotide sequence of the mouse MCK enhancer in the region of the myogenin-E12. binding site. Arrows above and below the sequence indicate guanines on the coding and noncoding strands that interfere with binding when methylated. The line in the center of the sequence denotes the $\kappa E 2$-like motif.

this region in the gel retardation assay, no binding of the myogenin-E12 heterodimer was detectable (Fig. 7B), whereas the same DNA fragment from the wild-type enhancer gave rise to a shifted complex in the presence of myogenin-E12. The DNA fragment used in these assays also contained the upstream $\kappa E 2$ motif that binds MyoDl (Lassar et al. 1989). These results confirm the 


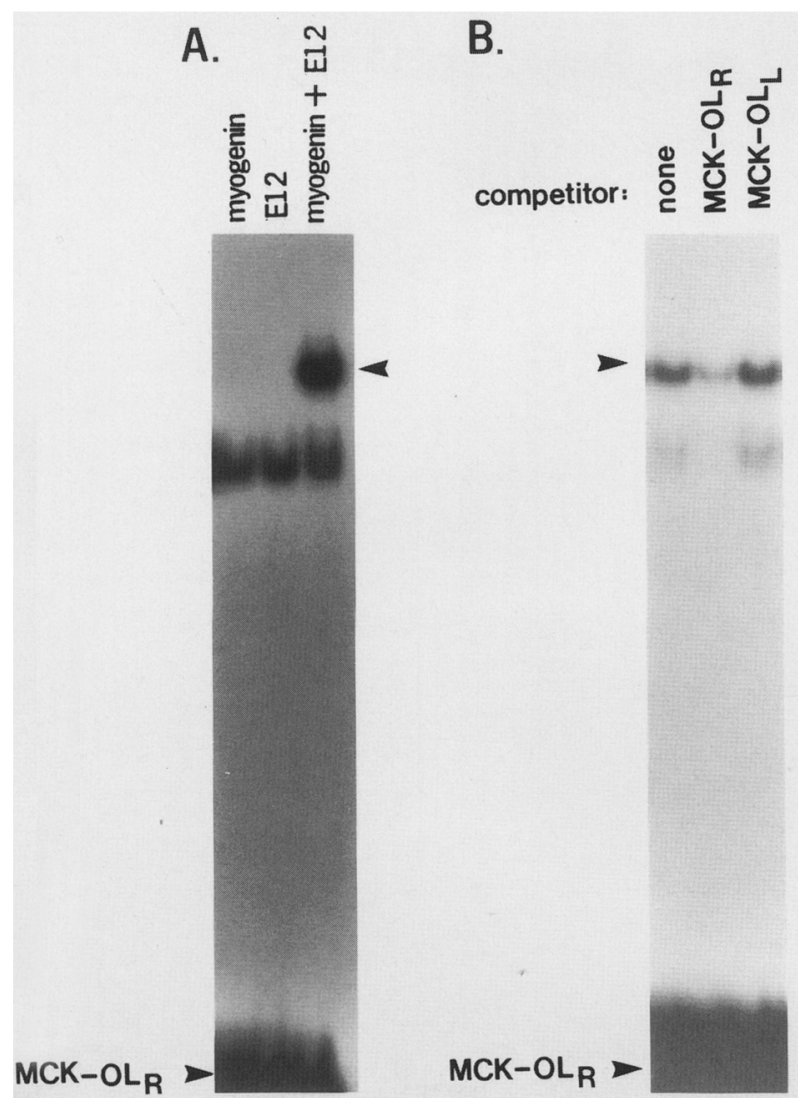

Figure 6. Binding of in vitro-translated myogenin-E12 to a synthetic oligomer corresponding to the downstream $\kappa E 2$ site from the MCK enhancer. $(A)$ A synthetic oligomer corresponding to the region of the MCK enhancer that encompasses the myogenin-E12 binding site (nucleotides -1159 to -1138 ) was end-labeled and used as a probe in gel retardation assays with in vitro-translation products of myogenin and E12, as indicated. The region of the enhancer encompassed by the oligomer, denoted MCK-OL $\mathrm{R}_{\mathrm{R}}$, is shown in Figure 7A. $(B)$ Binding of in vitro-translated myogenin-E12 to $M C K-O L_{R}$ in the presence of the homologous unlabeled oligomer or an oligomer corresponding to the upstream $\kappa E 2$-like motif, denoted $M C K-O L_{L}$ (see Fig. 7A).

results of the methylation interference assays and show that myogenin-E12 binds to one site in the enhancer under the assay conditions.

The functional importance of the myogenin-E12 binding site to the activity of the MCK enhancer was also examined by testing the ability of myogenin to trans-activate the wild-type and mutant MCK enhancers following transfection into $10 \mathrm{~T}^{1 / 2}$ cells. The complete MCK 5 ' enhancer is contained within the 302-bp region between -1350 and -1048 bp upstream of the transcription initiation site (Jaynes et al. 1988; Sternberg et al. 1988; Horlick and Benfield 1989). This enhancer shows no activity in $10 \mathrm{~T}^{1 / 2}$ cells, but can be trans-activated in these cells by myogenin (Edmondson and Olson 1989|. We therefore mutated the myogenin-binding site within this larger region and created a pair of reporter plasmids in which the wild-type and mutant enhancers were inserted $3^{\prime}$ of a CAT gene, which itself was fused to $246 \mathrm{bp}$ of the MCK promoter. CAT reporter genes containing the wild-type and mutant enhancers were then transfected transiently into $10 \mathrm{~T}^{1 / 2}$ cells with an expression vector encoding myogenin under transcriptional control of the Moloney sarcoma virus long terminal repeat. Whereas myogenin was able to trans-activate the wild-type MCK enhancer in $10 \mathrm{~T}^{1 / 2}$ cells, the enhancer that was mutated at the myogenin-E12-binding site was impaired in its ability to confer myogenin-dependent regulation on CAT (Fig. $7 \mathrm{C}$ ). When transfected at a ratio of $5: 1$ (CAT : myogenin), CAT expression from the mutant was not significantly different from background levels of expression from the MCK promoter alone. Thus, the myogenin-E12-binding region is important for trans-activation of the enhancer by myogenin in $10 \mathrm{~T}^{1 / 2}$ cells.

\section{Myogenin interacts with the MCK enhancer in nuclear extracts from differentiated $B C_{3} H 1$ and $C 2$ cells}

To establish whether myogenin interacts in vivo with the same site as myogenin-E12 produced in vitro, we examined whether nuclear extracts from $\mathrm{BC}_{3} \mathrm{H} 1$ and $\mathrm{C} 2$ cells contained factors that interacted with the oligomer corresponding to the myogenin-E12-binding site. We were particularly interested in comparing the spectrum of binding activities for the myogenin-E12 site in extracts from these cell lines because $\mathrm{C} 2$ cells express myogenin and $\mathrm{MyoDl}$ whereas $\mathrm{BC}_{3} \mathrm{Hl}$ cells express only myogenin (Davis et al. 1987; Edmondson and Olson 1989). We also examined extracts from $10 \mathrm{~T}^{1 / 2}$ cells for factors that may bind to the myogenin-E12 site.

The pattern of DNA-protein complexes generated with each of the extracts and the labeled oligomer is shown in Figure 8A. All of the extracts gave rise to a common DNA-protein complex, denoted complex-1. In addition, extracts from differentiated $\mathrm{BC}_{3} \mathrm{H} 1$ and $\mathrm{C} 2$ cells gave rise to a myocyte-specific DNA-protein complex, denoted complex-2. Interestingly, the pattern of DNA-protein complexes generated by $\mathrm{BC}_{3} \mathrm{H} 1$ and $\mathrm{C} 2$ extracts was similar to the labeled oligomer as probe. Complex-1 and -2 result from the binding of sequencespecific factors because they were eliminated in the presence of homologous, but not heterologous, DNA competitors. As shown in Figure 8B, competition with the oligomer corresponding to the myogenin-E12binding site $\left(\mathrm{MCK}-\mathrm{OL}_{\mathrm{R}}\right)$ abolished formation of the myocyte-specific complex- 2 from $\mathrm{BC}_{3} \mathrm{H} 1$ myocyte extracts, whereas oligomers corresponding to the upstream E-box $\left(M C K-O L_{L}\right)$ or the MEF-2-binding site had no effect on the formation of complex-2. Identical results were obtained with extracts from C2 myotubes (data not shown). Formation of complex-1 with extracts from $10 \mathrm{~T}^{1 / 2}$ cells (Fig. 8B) or myoblasts (data not shown), was also inhibited specifically by $M C K-O L_{R}$ but not by MCK-OL $L_{\mathrm{L}}$. Together, these results suggest that the myogenin-E12-binding site in the MCK enhancer interacts with a variety of sequence-specific factors and that this 


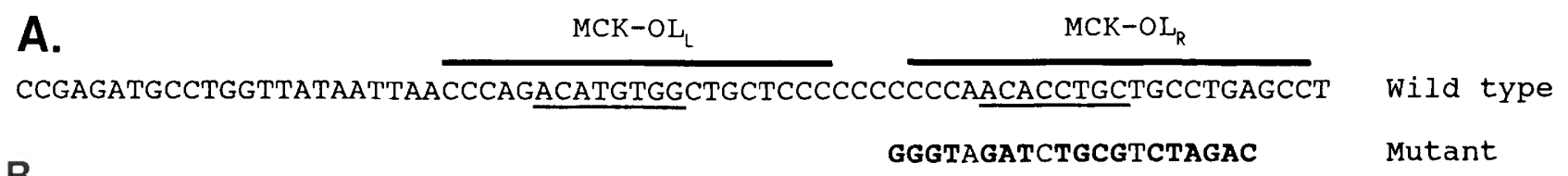

B.

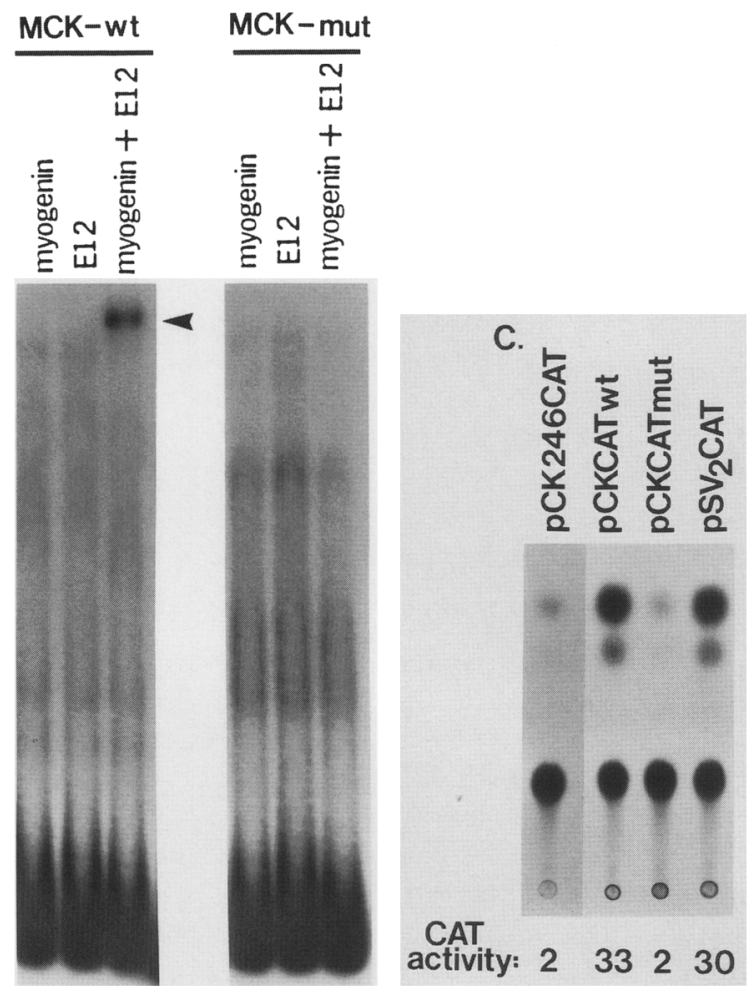

Figure 7. Mutagenesis of the myogenin-E12 binding site prevents trans-activation of the MCK enhancer by myogenin. (A) The sequence of the MCK enhancer core $(-1204$ to -1134$)$ is shown. The region of the enhancer core encompassing the myogenin-E 12 binding site was mutated. Sequences of the wild-type and mutant enhancer within this region are shown. The $\kappa E 2$-like sites are underlined and the sequences contained in the oligomers $M C K-O L_{L}$ and $M C K-O L L_{R}$, are indicated. $(B)$ A DNA fragment encompassing the region between -1269 and -1090 of the wild-type and mutant MCK enhancers was end-labeled and used in gel retardation assays with myogenin and E12 translated in vitro. The specific DNA-protein complex generated by myogenin-E12 is indicated with an arrow. $(C)$ A DNA fragment encompassing the region between -1350 and -1048 of the wild-type and mutant MCK enhancers was inserted 3' of CAT, in the vector pCK246CAT, which contains the 246-bp MCK promoter. Wild-type and mutant CAT constructions, designated pCKCATwt and pCKCATmut, respectively, in addition to pSV2CAT and pCK246CAT were transfected transiently into 10T $1 / 2$ cells in the presence of an expression vector encoding myogenin. Twenty-four hours after transfection, cultures were transferred to Dulbecco's modified Eagle medium (DMEM) containing 2\% horse serum for $48 \mathrm{hr}$. Levels of CAT expression are expressed as the percentage of $\left[{ }^{14} \mathrm{C}\right]$ chloramphenicol converted to acetylated products.

site may normally be occupied by factors in cells in which the enhancer is inactive.

To determine whether any of the mobility-shifted complexes observed with myocyte nuclear extracts were attributable to the binding of myogenin, antimyogenin antibody or preimmune serum was added to the gel retardation assay. In the presence of antimyogenin antibody, we observed a diminution in intensity of the myocyte-specific complex-2 generated by extracts from $\mathrm{BC}_{3} \mathrm{Hl}$ and $\mathrm{C} 2$ myocytes (Fig. $8 \mathrm{C}$; cf. lane 3 with 4 and lane 7 with 8). In contrast, preimmune serum had no measureable effect on the pattern of DNA-protein complexes formed with the labeled oligomer (Fig. 8C, lanes 5 and 9|. The identity of a component of the myocyte-specific complex-2 as myogenin was indicated further by the ability of excess myogenin peptides to prevent disruption of the complex by the antimyogenin antibody (Fig. 8C, lanes 6 and 10). The antimyogenin antibody had no effect on formation of complexes with extracts from $10 \mathrm{~T}^{1 / 2}$ cells (Fig. $8 \mathrm{C}$, lanes 1 and 2) or myoblasts (data not shown|. These results indicate that myogenin synthesized in vivo binds to the same site as in vitro-translated myogenin-E12.

It is apparent from the assays in Figure $8 \mathrm{C}$ that the antimyogenin antibody did not completely abolish formation of the myocyte-specific complex. We attempted to obtain more complete disruption of this complex by adding greater amounts of antimyogenin antibody to the assay, but did not observe a further decrease in the intensity of this complex (see Discussion). These results suggest that myocyte-specific factors in addition to myogenin may interact with the same region of the MCK enhancer as the myogenin-E12 heterodimer synthesized in vitro. Alternatively, a population of myogenin may be unable to react with the antimyogenin antibodies because peptide epitopes are masked, perhaps by heterodimerization with a different helix-loophelix protein.

\section{Discussion}

Myogenin binds as a heterodimer to a conserved motif in the core of the MCK enhancer

We showed previously that the MCK enhancer is active only in differentiated skeletal muscle cells (Sternberg et al. 1988, 1989; Gossett et al. 1989) and that myogenin can trans-activate this enhancer in $10 \mathrm{~T}^{1 / 2}$ cells, where it is normally inactive (Edmondson and Olson 1989). In the present study, we extend these observations to show that myogenin resides in the nucleus of differentiated muscle cells and interacts as a heterodimer with a single site in the core of the MCK enhancer.

By use of myogenin translated alone in vitro, we were unable to detect significant binding to the MCK enhancer. Similarly, MyoDl translated in vitro failed to 

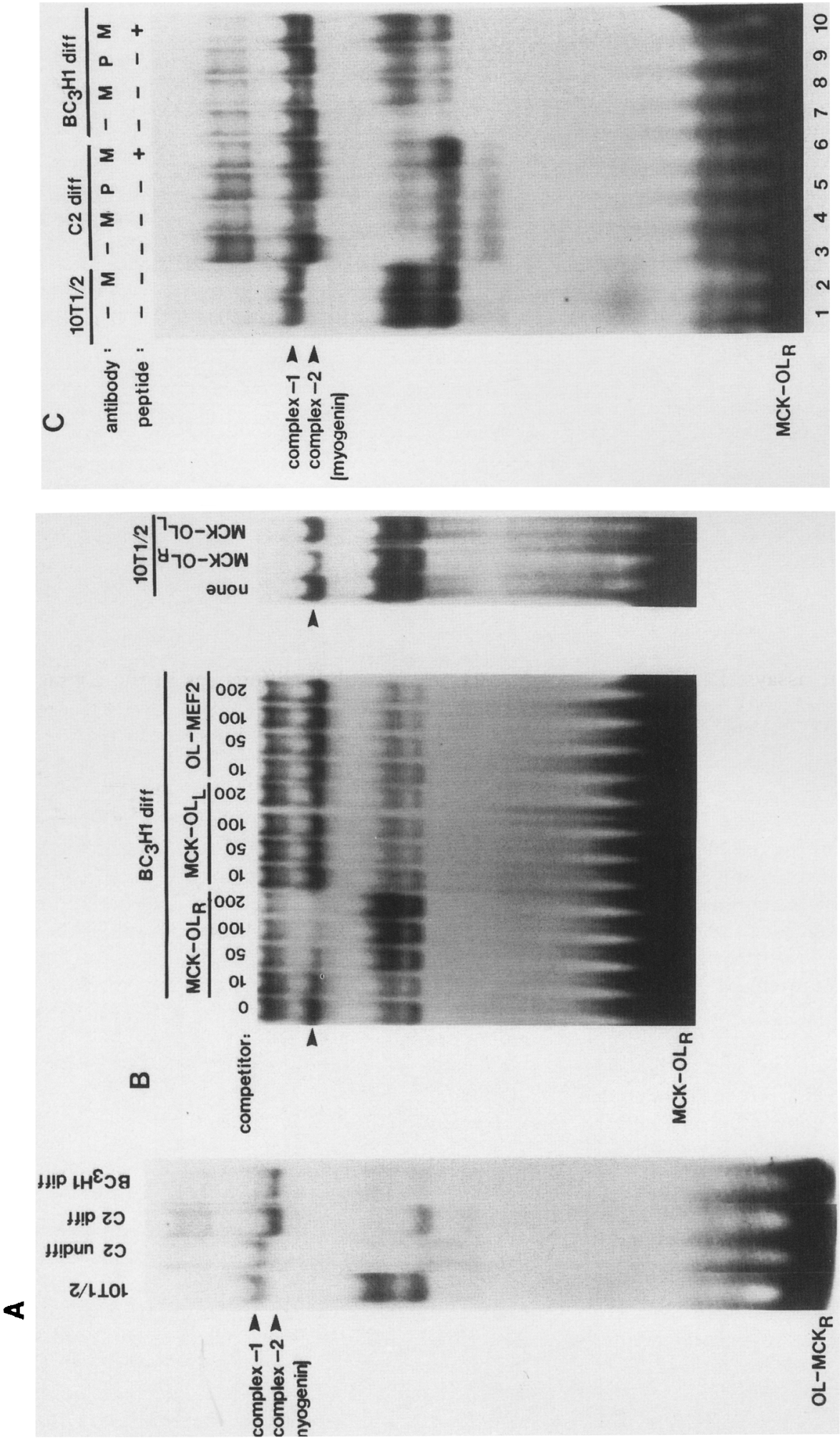

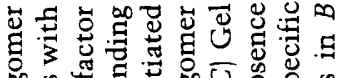

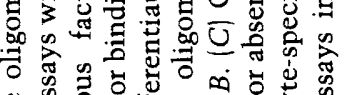

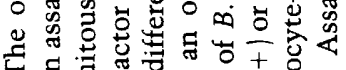

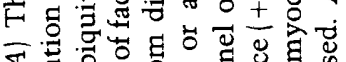

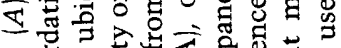

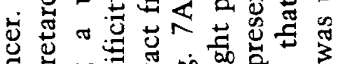

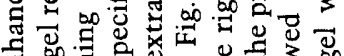

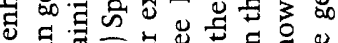

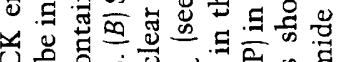

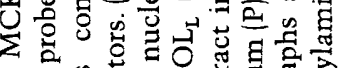

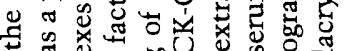

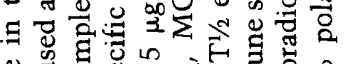

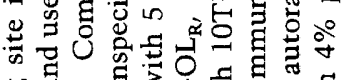

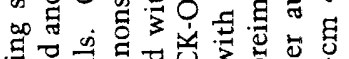

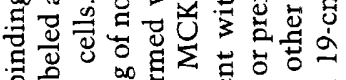

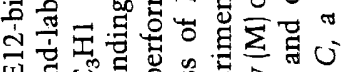

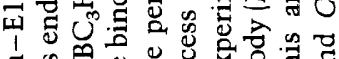

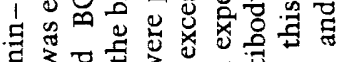

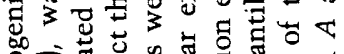

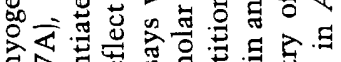

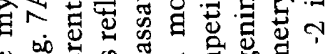

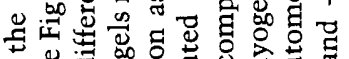
\&

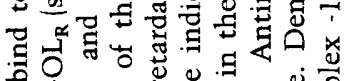

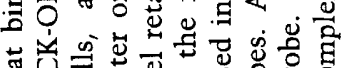

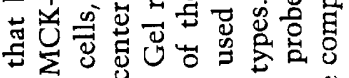

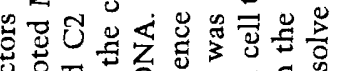

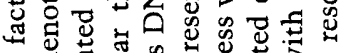

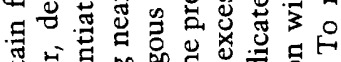

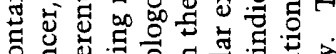

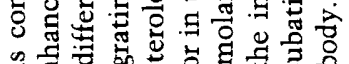

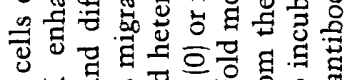

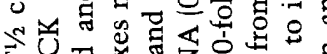

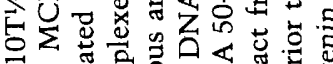

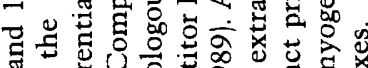

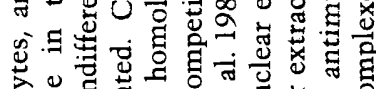

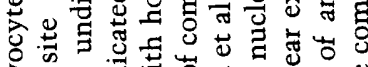

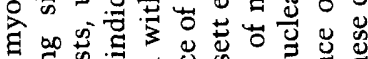

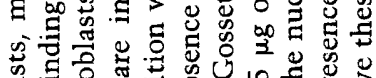

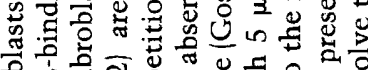

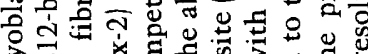

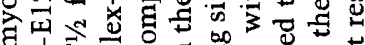

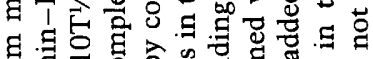
过会舟

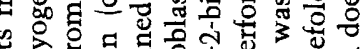

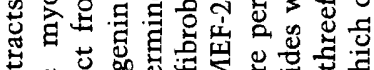

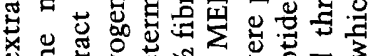

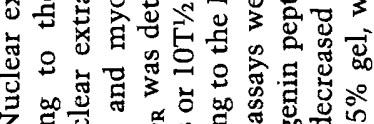
之 此势

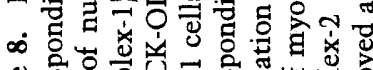

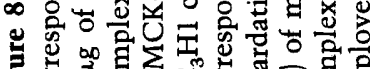

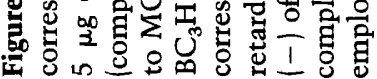


bind to the MCK enhancer alone or in combination with myogenin. In contrast, in the presence of the ubiquitous factor E12, myogenin formed a heterodimer and bound with high affinity and specificity to the enhancer. There was considerable selectivity in the factors with which myogenin would interact since it did not dimerize to a measureable extent with MyoDl or with the helixloop-helix protein USF, which is expressed constitutively in many cell types (M. Sawadogo, pers. comm.). The ability of myogenin to heterodimerize specifically with E12 is consistent with the recent proposal of Murre et al. $(1989 \mathrm{~b})$, that helix-loop-helix proteins can be divided into different classes on the basis of their cell-type distributions and abilities to form heterodimers. Ubiquitous proteins such as the daughterless gene product, E12, and E47 seem to dimerize preferentially with celltype-specific proteins such as the achaete scute gene product, MyoD1, and myogenin.

The lack of binding of in vitro-translated MyoD1 to the MCK enhancer agrees with the results of Murre et al. (1989b), but contrasts with recent results of Lassar and co-workers, who showed that bacterially expressed MyoD1 interacts with the MCK enhancer at two sites (Lassar et al. 1989). Bacterially expressed myogenin also has been found to bind to the MCK enhancer (W. Wright and A. Lassar, pers. comm.). A likely explanation for this disparity may be the high concentrations of bacterially expressed MyoD1 or myogenin necessary to detect sequence-specific binding. In their assays, Lassar et al. (1989) used up to $0.5 \mu \mathrm{g}$ of purified MyoD1, which we estimate to be at least three orders of magnitude higher than the amount present as a heterodimer with E12 in our in vitro-translation reactions. In vitro-translated myogenin also would presumably bind to the MCK enhancer when present at high concentrations. Considering the large quantities of bacterially expressed MyoDl that are required to detect binding to the MCK enhancer, it is questionable whether MyoDl normally binds alone to the enhancer in vivo, particularly because E12 has been reported to be ubiquitous (Murre et al. 1989a) and would presumably be available for heterodimerization with $\mathrm{MyoDl}$ or myogenin in myogenic cells. Assuming that oligomerization is required for binding, it seems likely that at high concentrations of MyoDl or myogenin in vitro, these proteins may form homodimers that can bind to the MCK enhancer. The ability of the helix-loop-helix protein E47 to form a homodimer at high concentrations has, in fact, been demonstrated (Murre et al. 1989a). That heterodimerization with E12 (or homodimerization at high concentrations) is required for interaction of myogenin with the MCK enhancer suggests that the basic domain of each member of the oligomer is important for mediating sequence-specific DNA binding. In this regard, mutations within the basic domain of myogenin do not affect heterodimerization with E12, but abolish the ability of the heterodimer to bind the enhancer (T.J. Brennan and E.N. Olson, in prep.).

The sequence in the MCK enhancer to which myogenin-E12 binds corresponds to the site for binding of
MyoDl (Lassar et al. 1989). The 10-bp motif, CACCTGCTGC, which constitutes this site, is conserved perfectly in the rat MCK enhancer (Horlick and Benfield 1989) and is also found in the rat myosin lightchain 1/3 enhancer (Donoghue et al. 1988), where it has been shown to bind MyoD1 (Lassar et al. 1989). Divergent versions of this motif are also found in regulatory regions of the chicken acetylcholine receptor $\alpha$-subunit (Wang et al. 1988), mouse acetylcholine receptor $\delta$-subunit (Baldwin and Burden 1988), quail troponin I (Yutzey et al. 1989), hamster desmin (Pieper et al. 1987), rat tropomyosin (Helfman et al. 1986), chicken $\alpha$-cardiac actin (Quitschke et al. 1989), and mouse myogenin and MRF-4 (D.E. Edmondson, T.C. Cheng, and E.N. Olson, unpubl.) genes. A similar sequence, referred to as a $\mathrm{kE} 2$ motif or E-box, has also been identified within the enhancers of several genes that are not specific to skeletal muscle, such as the immunoglobulin heavy- and light-chain enhancers (Church et al. 1985; Ephrussi et al. 1985; Sen and Baltimore 1986; Lenardo et al. 1987) and the insulin enhancer (Moss et al. 1988). Although these various Eboxes share the motif NCANNTGN, there are clearly additional sequence requirements for binding of different helix-loop-helix proteins, as demonstrated by the inability of the myogenin-E12 heterodimer to bind with high affinity to the upstream E-box in the MCK enhancer. Moreover, even between different heterodimers that recognize the same site, methylation interference reveals subtle differences in the contact points (Murre et al. 1989b). In this regard, bacterially expressed MyoDl shows a different pattern of methylation interference from that of myogenin-E12 over the downstream E-box in the MCK enhancer.

Site-directed mutagenesis showed that the downstream E-box in the MCK enhancer is important for activation of the enhancer by myogenin in $10 \mathrm{~T}^{1 / 2}$ cells. This element is also required for muscle-specific activity of this enhancer in differentiated $\mathrm{C} 2$ myotubes (Buskin and Hauschka 1989; Lassar et al. 1989; E. Sternberg and E.N. Olson, in prep.). It should be pointed out, however, that although the myogenin-E12-binding site is essential for high-level activity of the enhancer in muscle cells, it is not the only site within this enhancer that interacts with sequence-specific DNA-binding factors (Gossett et al. 1989; Buskin and Hauschka 1989; Horlick and Benfield 1989), nor is this site alone sufficient to generate high-level muscle-specific enhancer activity. Moreover, mutagenesis of adjacent regions of the enhancer core that do not affect binding of myogenin or MyoDl result in a dramatic loss of enhancer activity (E. Sternberg and E.N. Olson, unpubl.). The observation that the myogenin-E12-binding site is necessary, but not sufficient, for enhancer activity indicates that interactions between factors at the enhancer is highly cooperative.

It is not clear why myogenin and MyoDl, which are coexpressed in many muscle-cell types, should both bind to the same site in the MCK enhancer. Several possibilities can be envisioned. Myogenin and MyoD1 could differ with respect to the proteins with which they in- 
teract and could, in principle, exhibit different specificities as activators of muscle genes. Alternatively, the distinct temporal and cell-type-specific patterns of expression of myogenin and MyoDl could determine the pattern of gene expression in a particular muscle-cell type. Finally, because MyoDl appears to possess the potential to interact with the E-box located upstream from the myogenin-E12-binding site, it is also conceivable that myogenin and MyoDl could bind simultaneously to the MCK enhancer in muscle cells that express both factors. This possibility is attractive, in light of the fact that putative MyoD1 and myogenin binding sites occur in pairs within regulatory regions of numerous musclespecific genes. It should also be emphasized, however, that muscle-specific genes are expressed normally in several muscle-cell lines that do not express MyoD1 (Braun et al. 1989b; Edmondson and Olson 1989; Wright et al. 1989|, whereas there have not been any reported examples of muscle-cell types that do not express myogenin.

\section{The binding site for myogenin serves as a site for binding of numerous factors}

The site in the MCK enhancer that binds myogenin has also been reported by Hauschka and co-workers to interact with a myocyte-specific factor, referred to as MEF-1, which is expressed during differentiation of the MM14 and $\mathrm{C} 2 \mathrm{C} 12$ muscle-cell lines (Buskin and Hauschka 1989). Using antibodies against MyoDl, Lassar et al. (1989) reported that MyoD1 shares antigenic similarity with MEF-1.

By use of nuclear extracts from $\mathrm{BC}_{3} \mathrm{Hl}$ and $\mathrm{C} 2$ cells in gel retardation assays, we observed a myocyte-specific complex with the myogenin-E12-binding site as a labeled probe. Since this complex was recognized specifically by antibodies directed against segments of myogenin that share no homology with the other known myogenic regulatory factors, we conclude that myogenin synthesized in vivo binds (probably as a component of a complex) to the same site in the MCK enhancer as myogenin-E12 produced in vitro. The fact that myogenin binds to the MCK enhancer in extracts from $\mathrm{C} 2$ cells, which coexpress myogenin and MyoD1, also indicates that myogenin can bind in the presence of MyoDl.

It is intriguing that nuclear extracts from $\mathrm{C} 2$ and $\mathrm{BC}_{3} \mathrm{Hl}$ myoblasts and $10 \mathrm{~T}^{1 / 2}$ cells, none of which expresses myogenin, also contain factors that interact specifically with the myogenin-binding site. The identities of these factors will be particularly interesting because their binding is apparently insufficient for transcriptional activation. Perhaps these factors antagonize the actions of myogenin.

The actions of myogenin may be dictated by factors with which it can interact

Although myogenin clearly shows high affinity for E12 in vitro, the present results do not allow us to conclude whether myogenin normally interacts with $\mathrm{E} 12$ in vivo. E12 has been reported to be expressed ubiquitously (Murre et al. 1989a), so it or a similar factor is likely to be available for heterodimerization with myogenin in muscle cells. In this context, we have isolated cDNAs from a $\mathrm{BC}_{3} \mathrm{Hl}$ myocyte cDNA library encoding at least three distinct types of helix-loop-helix proteins with homology to segments of E12 and E47 (L. Li and E.N. Olson, unpubl.). The apparent dependence of myogenin on E12, and perhaps other helix-loop-helix proteins, for activity indicates that the susceptibility of various cell types to the actions of myogenin may be dictated by the nature of the cellular factors with which myogenin may interact. This may begin to explain the resistance of certain cell types to myogenic conversion by myogenin (D. Edmondson and E.N. Olson, unpubl.) and MyoD1 (Weintraub et al. 1989). If, in certain cell types, for example, E12 were absent or other helix-loop-helix proteins were present, the activity of myogenin or MyoDl could be modulated.

In addition to being expressed during myoblast differentiation, myogenin has been shown to be expressed at high levels in the myotome at 8.5 days of development, prior to the appearance of differentiated muscle (Sassoon et al. 1989; Wright et al. 1989). The expression of myogenin at this early stage of development suggests that it may function in establishing the myogenic lineage. It is interesting to speculate that the apparent dual role of myogenin as a regulator of myogenic determination and differentiation may be dependent on its interactions with unique sets of helix-loop-helix proteins. Future studies will address the mechanisms that modulate myogenin's activities in different cell types during determination and differentiation of the myogenic lineage.

\section{Materials and methods}

\section{Cell culture and metabolic labeling}

The C2 (Yaffe and Saxel 1977), $\mathrm{BC}_{3} \mathrm{H1}$ (Schubert et al. 1974), and $10 \mathrm{~T}^{1 / 2}$ (Reznikoff et al. 1973) cell lines were cultured as described previously (Edmondson and Olson 1989). Labeling with $\left[{ }^{35} \mathrm{~S}\right]$ methionine was performed as described (Olson et al. 1983), except that cultures were incubated with isotope for $5 \mathrm{hr}$. At the end of the labeling period, nuclear extracts were prepared as described below.

\section{Peptide synthesis and immunization}

Peptides (MP1: PGYERTELSLSPEAR; MP2: SSLNQEERDLRYRGG) were synthesized by the Macromolecular Synthesis Facility at the MD Anderson Cancer Center (Houston, Texas). To cross-link peptides to Keyhole Limpet hemocyanin (Sigma), peptide $[1 \mathrm{mg} / \mathrm{ml}$ in phosphate-buffered saline (PBS)] and carrier protein $(1 \mathrm{mg} / \mathrm{ml}$ in PBS) were combined in a $1: 1$ ratio, to which $16 \mu$ l of $2.5 \%$ glutaraldehyde (final concentration $=4$ $\mathrm{mM}$ ) was added per milliliter, and the total volume mixed on a rotator for $30 \mathrm{~min}$ at room temperature. The peptide-protein conjugates were then dialyzed for $5 \mathrm{hr}$ in PBS. An equivalent of $500 \mu \mathrm{g}$ of peptide was injected in Freund's complete adjuvant into New Zealand White rabbits which were boosted every 3 weeks with $250 \mu \mathrm{g}$ in Freund's incomplete adjuvant. Injections were performed by Bethyl Laboratories (Montgomery, Texas). 


\section{Affinity purification}

MP1/MP2-conjugated epoxy-activated Sepharose 6B was prepared according to manufacturer's recommendations (Pharmacia). Briefly, 2 grams of epoxy-activated Sepharose 6B resin was swelled in water for $15 \mathrm{~min}$ and washed in a scinterred glass funnel with $200 \mathrm{ml}$ of water. Two milliliters of $30 \mu \mathrm{M}$ MP1 or MP2 (pH 11.0 in water) was mixed with the resin on a shaker for $16 \mathrm{hr}$ at $37^{\circ} \mathrm{C}$. The resin was then washed in a scinterred glass funnel with $100 \mathrm{ml}$ of each of the following: water, $0.1 \mathrm{M} \mathrm{NaHCO}_{3}(\mathrm{pH} 8.0)$, water, $0.1 \mathrm{M}$ sodium acetate $(\mathrm{pH} 4.0)$, and water. The excess reactive groups were then blocked with 1 $M$ ethanolamine at $42^{\circ} \mathrm{C}$ for $12 \mathrm{hr}$. The coupled resin was then washed in a scinterred glass funnel with $100 \mathrm{ml}$ of $0.1 \mathrm{M}$ sodium acetate $(\mathrm{pH} 4.0) / 0.5 \mathrm{M} \mathrm{NaCl}$ followed by $0.1 \mathrm{M}$ borate $(\mathrm{pH}$ $8.0) / 0.5 \mathrm{M} \mathrm{NaCl}$, and $10 \mathrm{~mm}$ Tris $(\mathrm{pH} 7.5)$ before $1 \mathrm{ml}$ of the coupled resin was loaded onto a 10-ml Dispo column (Bio-Rad) and washed with 20 bed volumes of each of the following: 10 $\mathrm{mm}$ Tris (pH 7.5), $100 \mathrm{~mm}$ glycine ( $\mathrm{pH} 2.5), 10 \mathrm{~mm}$ Tris (pH 8.8), and $10 \mathrm{~mm}$ Tris $(\mathrm{pH} 7.5)$. For affinity purification, $10 \mathrm{ml}$ of a $1: 4$ dilution of either anti-MP1 or anti-MP2 serum in $10 \mathrm{~mm}$ Tris $(\mathrm{pH} 7.5$ ) was loaded onto the $1-\mathrm{ml}$ MP1 or MP2 affinity column, respectively. The serum was passed through the column 4 times by gravity, and the column was then washed with 20 bed volumes of each of the following: $10 \mathrm{~mm}$ Tris (pH 7.5), $500 \mathrm{~mm} \mathrm{NaCl} / 10 \mathrm{~mm}$ Tris $(\mathrm{pH} 7.5)$, and $10 \mathrm{~mm}$ Tris $(\mathrm{pH} 7.5)$. The bound antibodies were eluted with 100 mM glycine $(\mathrm{pH} 2.5)$, and $1-\mathrm{ml}$ fractions were collected and immediately neutralized with $200 \mu \mathrm{l}$ of $2 \mathrm{M}$ Tris $(\mathrm{pH} 8.0)$. The peak fractions were combined and concentrated using microconcentrators (Amicon). One milliliter of immune serum would typically yield $150-200 \mu \mathrm{g}$ of affinity-purified antibody. Purified serum against both peptides was combined for all subsequent experiments.

\section{Immunofluorescence}

Cells were grown on plastic petri dishes, washed three times in PBS, fixed for $10 \mathrm{~min}$ in freshly prepared $2 \%$ paraformaldehyde/PBS, washed three times in PBS, incubated for $10 \mathrm{~min}$ in $0.15 \%$ Triton X-100/PBS, and washed 3 times in PBS. The cells were then blocked for 30-60 min in PBS containing $2 \%$ bovine serum albumin, incubated with a $1: 20$ dilution of purified anti-MPl/MP2 $(200 \mu \mathrm{g} / \mathrm{ml})$ in blocking buffer for from $4 \mathrm{hr}$ to overnight, and washed 3 times for $10 \mathrm{~min}$ in blocking buffer. The dishes were incubated for $1-2 \mathrm{hr}$ in fluorescein-conjugated goat anti-rabbit $\operatorname{IgG}(1: 1000$, Cappel $)$ in blocking buffer, and washed 4 times, for 15 min each wash, in blocking buffer before being visualized at $495-\mathrm{nm}$ wavelength.

\section{Preparation of nuclear extracts}

Nuclear extracts were prepared according to a slightly modified method of Dignam et al. (1983), as described by Gossett et al. (1989), with the exception that the dialysis buffer consisted of $100 \mathrm{mM} \mathrm{KCl}, 20 \mathrm{~mm}$ HEPES (pH 7.9), $0.2 \mathrm{~mm}$ EDTA, $0.5 \mathrm{~mm}$ phenylmethylsulfonyl fluoride, $0.5 \mathrm{mM}$ DTT, $20 \%$ (vol/vol) glycerol. Metabolically labeled nuclear extracts were not dialyzed.

\section{Immunoprecipitation}

For in vitro translations, $20 \mu \mathrm{l}$ of affinity-purified anti-MP1/ MP2 $(200 \mu \mathrm{g} / \mathrm{ml}), 300 \mu$ l RIPA buffer [10 mM Tris (pH 7.4), 150 $\mathrm{mm} \mathrm{NaCl}, 1 \% \mathrm{NP}-40,1 \%$ sodium deoxycholate, $0.1 \% \mathrm{SDS}]$, and $25 \mu$ l of the in vitro translation (see below) were incubated on a rotator at $4^{\circ} \mathrm{C}$ for $2 \mathrm{hr}$ before addition of $100 \mu \mathrm{l}$ of a $10 \%$ suspension of formalin-fixed Staphylococcus aureus. For nuclear extracts, $750 \mu l$ of RIPA buffer, $20 \mu \mathrm{l}$ preimmune sera, and $250 \mu \mathrm{l}$ of nuclear extract was incubated for $1 \mathrm{hr}$, to which 100 $\mu \mathrm{l}$ of $S$. aureus was added for $1 \mathrm{hr}$. The $S$. aureus was precipitated, and $40 \mu \mathrm{l}$ of anti-MP1/MP2 $(200 \mu \mathrm{g} / \mathrm{ml})$ was added to the supernatant and rotated overnight. $S$. aureus cells $(100 \mu \mathrm{l})$ were then added and rotated for $1 \mathrm{hr}$ at $4^{\circ} \mathrm{C}$. Immunoprecipitates from in vitro translations and nuclear extracts were washed 3 times by resuspension in $1 \%$ Triton $\mathrm{X}-100$ and $1.0 \mathrm{M} \mathrm{NaCl}$ in PBS, and layering over a solution of $1 \%$ Triton X-100, $1 \mathrm{M}$ sucrose in PBS, and reprecipitated. The pellets were then washed in PBS before being resuspended in sample buffer $[0.25 \mathrm{M}$ Tris [pH 6.8), 2\% SDS, 4\% $\beta$-mercaptoethanol, $10 \%$ glycerol] and resolved on $0.1 \%$ SDS $/ 10 \%$ polyacrylamide gels. For peptide competition, $50 \mu \mathrm{l}$ of a $15 \mu \mathrm{M}$ mixture of MP1 and MP2 in water was preincubated with the anti-MP1/MP2 antiserum for $\mathrm{l} \mathrm{hr}$ before addition to the binding reaction. For nondenaturing conditions, immunoprecipitates were prepared according to the method of Murre et al. (1989b).

\section{In vitro transcription and translation}

The myogenin vector used for in vitro transcription contained a full-length mouse myogenin cDNA cloned into the EcoRI site of pBluescript (Stratagene). Plasmid E12 (Murre et al. 1989a) was a gift from C. Murre and D. Baltimore. Plasmid PVZC11B, containing mouse MyoD1, was a gift from A. Lassar. RNA synthesis was performed using $1 \mu \mathrm{g}$ of linearized plasmid and 10 units of $\mathrm{T} 3$ polymerase in a $25-\mu \mathrm{l}$ reaction volume for $1 \mathrm{hr}$ at $37^{\circ} \mathrm{C}$ as suggested by the manufacturer (Stratagene, mRNA Capping Kit). After extraction with phenol/chloroform, the RNA was precipitated and resuspended in $25 \mu$ l of TE [10 mM Tris $\{\mathrm{pH} 7.6\}, 1 \mathrm{mM}$ EDTA|. Two $\mu 1$ of the RNA was used for in vitro translation with rabbit reticulocyte lysate in a $50-\mu l$ reaction volume as recommended by the manufacturer (Promega). The reactions were allowed to proceed for $1 \mathrm{hr}$ at $30^{\circ} \mathrm{C}$.

\section{Gel retardation assays and methylation interference}

The indicated in vitro-translation products $(3 \mu \mathrm{l})$ or $5 \mu \mathrm{g}$ of the indicated nuclear extracts was incubated for $5 \mathrm{~min}$ at room temperature with $1 \mu \mathrm{g}$ poly[d(I-C)], $2 \mu \mathrm{l}$ of $10 \times$ binding buffer [final concentrations, $40 \mathrm{~mm} \mathrm{KCl}, 15 \mathrm{~mm}$ HEPES $\mid \mathrm{pH} 7.9$ ), $1 \mathrm{~mm}$ EDTA, $0.5 \mathrm{mM}$ DTT, and 5\% glycerol], and the indicated concentrations of DNA competitors in a $20-\mu$ l reaction volume. DNA competitors $(90 \mathrm{ng}$ ) were used unless indicated otherwise. End-labeled enhancer fragments were then added and allowed to incubate for an additional $20 \mathrm{~min}$ before being loaded onto either $4 \%$ or $5 \%$ polyacrylamide gels and electrophoresed at 175 volts. Synthetic oligomers encompassing either of the two $\mathrm{E}$-boxes in the MCK enhancer core were cloned into the BamHI site of pUC19 using 10-bp BamHI linkers and were excised from the vector by digestion with BamHI. The enhancer core $(-1204$ to -1134$)$ and the peripheral region containing the MEF-2 site ( -1094 to -1048$)$ were cloned into the BamHI site of pUC19 and were excised with BamHI (Gossett et al. 1989). For assays involving antibody disruption, $8 \mu \mathrm{l}$ of affinity-purified anti-MP1/MP2 $(150 \mu \mathrm{g} / \mathrm{ml}$, dialyzed in $1 \times$ binding buffer $)$ or preimmune serum (dialyzed in $1 \times$ binding buffer) was preincubated with the extracts in the binding mixture for $10 \mathrm{~min}$ before addition of the probe. For peptide competition analysis, 2 $\mu \mathrm{l}$ of a $15 \mu \mathrm{M}$ solution of MP1/MP2 in water was preincubated with the antibody in the binding reaction mixture for $10 \mathrm{~min}$ before the addition of nuclear extract. Methylation interference 
and $A+G$ reactions were performed as described previously (Baldwin and Sharp 1988).

\section{Preparation of reporter genes and transient transfections}

The MCK enhancer was assayed by inserting a 302-bp fragment encompassing the region between -1350 and -1048 into the unique BamHI site of the vector pCK246CAT (Sternberg et al. 1988), which contains the MCK basal promoter fused immediately upstream of CAT. This vector was referred to previously as pCKCATe4 (Stemberg et al. 1988). Mutagenesis was performed by cloning the 302 -bp enhancer fragment into the $B a m H I$ site of M13. A mutant oligomer was used to create the site-specific mutation at the myogenin-E12 binding site. The mutant 302-bp fragment was then recloned into pCK246CAT, and its identity was verified by sequencing. Mutant and wildtype enhancers in the + and - orientation were tested in transfection assays with the same results.

$10 \mathrm{~T}^{1 / 2}$ cells were transfected transiently as described previously (Stemberg et al. 1988) with $10 \mu \mathrm{g}$ of CAT reporter plasmids and $2 \mu \mathrm{g}$ of an expression vector encoding full-length mouse myogenin under transcriptional control of the Moloney sarcoma virus long terminal repeat (Edmondson and Olson 1989). Twenty-four hours after transfection, cultures were transferred to DMEM with $2 \%$ horse serum for $48 \mathrm{hr}$. Cells were then harvested and CAT activity was assayed as described (Sternberg et al. 1988). Transfections were performed three times with two separate plasmid preparations with similar results.

\section{Acknowledgments}

We thank E. Sternberg for the mutated MCK enhancer, D.G. Edmondson for myogenin expression vectors and for helpful discussions, W. Michael Perry for critical comments on the manuscript, and Mamta Kalides for help with initial antibody characterization. We are grateful to C. Murre and D. Baltimore for the gift of E12 and to A. Lassar for MyoD1. We also acknowledge S. Jasser for tissue culture, M.E. Perry for technical assistance, and E. Madson for help in preparing the manuscript. This work has been supported by grants from the National Institutes of Health (NIH) and the American Cancer Society (ACS) to E.N.O., who is an Established Investigator of The American Heart Association. T.J.B. has been supported in part by an NIH training grant.

\section{References}

Alonso, M.C. and C.V. Cabrera. 1988. The achaete-scute complex of Drosophila melanogaster comprises four homologous genes. EMBO I. 7: 2585-2591.

Baldwin, A. and P. Sharp. 1988. Two transcription factors, $\mathrm{H} 2 \mathrm{tf} 1$ and NFKB, interact with a single regulatory sequence in the class 1 MHC promoter. Proc. Natl. Acad. Sci. 85: $723-727$.

Baldwin, T.J. and S.J. Burden. 1988. Isolation and characterization of the mouse acetylcholine receptor $\delta$-subunit gene: Identification of a 148-bp cis-acting region that confers myotube-specific expression. I. Cell Biol. 107: 2271-2279.

- 1989. Muscle-specific gene expression controlled by a regulatory element lacking a MyoD1-binding site. Nature 341: 716-720.

Battey, J., C. Moulding, R. Taub, W. Murphy, T. Stewart, H. Potter, G. Lenoir, and P. Leder. 1983. The human c-myc on- cogene: Structural consequences of translocation into the IgH locus in Burkitt lymphoma. Cell 34: 779-787.

Braun, T., E. Bober, G. Buschhausen-Denker, S. Kotz, K. Grzeschik, and H.H. Arnold. 1989a. Differential expression of myogenic determination genes in muscle cells: Possible autoactivation by the Myf gene products. EMBO I. 8: 36173625.

Braun, T., G. Buschhausen-Denker, E. Bober, E. Tannich, and H.H. Arnold. 1989b. A novel human muscle factor related to but distinct from MyoDl induces myogenic conversion in 10T $1 / 2$ fibroblasts. EMBO I. 8: 701-709.

Brennan, T.J., D.E. Edmondson, and E.N. Olson. 1990. Aberrant regulation of MyoDl contributes to the partially defective myogenic phenotype of the $\mathrm{BC}_{3} \mathrm{H} 1$ muscle cell line. I. Cell Biol. (in press).

Buskin, J.N. and S.D. Hauschka. 1989. Identification of a myocyte-specific nuclear factor which binds to the muscle-specific enhancer of the mouse muscle creatine kinase gene. Mol. Cell. Biol. 9: 2627-2640.

Caudy, M., H. Vässin, M. Brand, R. Tuma, L. Yeh Jan, and Y.N. Jan. 1988. daughterless a Drosophila gene essential for both neurogenesis and sex determination, has sequence similarities to myc and the achaete-scute complex. Cell 55: 10611067.

Church, G.M., A. Ephrussi, W. Gilbert, and S. Tonegawa. 1985. Cell type specific contacts to immunoglobulin enhancers in nuclei. Nature 313: 798-801.

Cronmiller, C., P. Schedl, and R.W. Cline. 1988. Molecular characterization of daughterless, a Drosophila sex determination gene with multiple roles in development. Genes Dev. 2: $1666-1676$.

Davis, R.L., H. Weintraub, and A.B. Lassar. 1987. Expression of a single transfected cDNA converts fibroblasts to myoblasts. Cell 51: $987-1000$.

DePinho, R.A., E. Legouy, L.B. Feldman, N.E. Kohl, G.D. Yancopoulos, and F.W. Alt. 1986. Structure and expression of the murine N-myc gene. Proc. Natl. Acad. Sci. 83: 18271831.

Dignam, J.D., R.M. Lebovitz, and R.G. Roeder. 1983. Accurate transcription initiation by RNA polymerase II in a soluble extract from isolated mammalian nuclei. Nucleic Acids Res. 11: $1475-1489$.

Donoghue, M., H. Ernst, B. Wentworth, B. Nadal-Ginard, and N. Rosenthal. 1988. A muscle-specific enhancer is located at the $3^{\prime}$ end of the myosin light chain $1 / 3$ gene locus. Genes Dev. 2: $1779-1790$.

Edmondson, D.G. and E.N. Olson. 1989. A gene with homology to the myc similarity region of MyoDl is expressed during myogenesis and is sufficient to activate the muscle differentiation program. Genes Dev. 3: 628-640.

Ephrussi, A., G.M. Church, S. Tonegawa, and W. Gilbert. 1985. B-lineage-specific interactions of an immunoglobulin enhancer with cellular factors in vivo. Science 227: 134-140.

Gossett, L.A., D. Kelvin, E. Sternberg, and E.N. Olson. 1989. A new myocyte-specific enhancer binding factor that recognizes a conserved element associated with multiple musclespecific genes. Mol. Cell. Biol. 9: 5022-5033.

Helfman, D.M., S. Cheley, E. Kuismanen, L.A. Finn, and Y. Yamawaki-Kataoka. 1986. Nonmuscle and muscle tropomyosin isoforms are expressed from a single gene by alternative RNA splicing and polyadenylation. Mol. Cell. Biol. 6: $3582-3595$.

Horlick, R.A. and P.A. Benfield. 1989. The upstream musclespecific enhancer of the rat muscle creatine kinase gene is composed of mutiple elements. Mol. Cell. Biol. 9: 23962413. 
Jaynes, J.B., J.E. Johnson, J.N. Buskin, C.L. Gartside, and S.D. Hauschka. 1988. The muscle creatine kinase gene is regulated by multiple upstream elements, including a musclespecific enhancer. Mol. Cell. Biol. 8: 62-70.

Klaembt, C., E. Knust, K. Tietze, and J.A. Campos-Ortega. 1989. Closely related transcripts encoded by the neurogenic gene comples Enhancer of split of Drosophila melanogaster. $E M B O$ I. 8: 203-210.

Lassar, A.B., J.N. Buskin, D. Lockshon, R.L. Davis, S. Apone, S. D. Hauschka, and H. Weintraub. 1989. MyoD is a sequencespecific DNA binding protein requiring a region of myc homology to bind to the muscle creatine kinase enhancer. Cell 58: $823-831$.

Lenardo, M., J.W. Pierce, and D. Baltimore. 1987. Proteinbinding sites in Ig enhancers determine transcriptional activity and inducibility. Science 236: 1573-1577.

Maxam, A.M., and W. Gilbert. 1980. Sequencing end-labeled DNA with base-specific chemical cleavages. Methods Enzymol. 65: 449-560.

Mellentin, J.D., S.D. Smith, and M.L. Cleary. 1989. lyl-1, a novel gene altered by chromosomal translocation in $\mathrm{T}$ cell leukemia, codes for a protein with a helix-loop-helix DNA binding motif. Cell 58: 77-83.

Moss, L.G., J.B. Moss, and W.J. Rutter. 1988. Systematic binding analysis of the insulin gene transcription control region: Insulin and immunoglobulin enhancers utilize similar transactivators. Mol. Cell. Biol. 8: 2620-2627.

Murre, C., P.S. McCaw, and D. Baltimore. 1989a. A new DNA binding and dimerization motif in immunoglobulin enhancer binding, daughterless, $M y o D$, and myc proteins. Cell 56: $777-783$.

Murre, C., P.S. McCaw, H. Vaessin, M. Caudy, L.Y. Jan, Y.N. Jan, C.V. Cabrera, J.N. Buskin, S.D. Hauschka, A.B. Lassar, H. Weintraub, and D. Baltimore. 1989b. Interactions between heterologous helix-loop-helix proteins generate complexes that bind specifically to a common DNA sequence. Cell 58: 537-544.

Olson, E.N., K.C. Caldwell, J.I. Gordon, and L. Glaser. 1983. Regulation of creatine phosphokinase expression during differentiation of $\mathrm{BC}_{3} \mathrm{Hl}$ muscle cell line. J. Biol. Chem. 258: $2644-2652$.

Pieper, F.R., R.L. Slobbe, F.C.S. Ramaekers, H.T. Cuypers, and H. Bloemendal. 1987. Upstream regions of the hamster desmin and vimentin genes regulate expression during in vitro myogenesis. EMBO J. 6: 3611-3618.

Pinney, D.F., S.H. Pearson-White, S.F. Konieczny, K.E. Latham, and C.P. Emerson, Jr. 1988. Myogenic lineage determination and differentiation: Evidence for a regulatory gene pathway. Cell 53: 781-793.

Quitschke, W.W., L. DePonti-Zilli, Z.E.-Y. Lin, and B.M. Patterson. 1989. Identification of two nuclear factor-binding domains on the chicken cardiac actin promoter: Implications for regulation of the gene. Mol. Cell. Biol. 9: 32183230 .

Reznikoff, C.A., D.W. Brankow, and C. Heidelberger. 1973. Establishment and characterization of a cloned line of $\mathrm{C} 3 \mathrm{H}$ mouse embryo cells sensitive to postconfluence inhibition of division. Cancer Res. 33: 3231-3238.

Rhodes, S.J. and S.F. Konieczny. 1989. Identification of MRF4: a new member of the muscle regulatory factor gene family. Genes Dev. 3: 2050-2061.

Rosenthal, N. 1989. Muscle cell differentiation, review. Curr. Opin. Cell Biol. (in press).

Rushlow, C.A., A. Hogan, S.M. Pinchin, K.M. Howe, M. Lardelli, and D. Ish-Horowicz. 1989. The Drosophila hairy protein acts in both segmentation and bristle patterning and shows homology to N-myc. EMBO J. 8: 3095-3103.

Sassoon, D., G. Lyons, W.E. Wright, V. Lin, A. Lassar, H. Weintraub, and M. Buckingham. 1989. Expression of two myogenic regulatory factors myogenin and MyoDl during mouse embryogenesis. Nature 341: 303-307.

Schubert, D., J. Harris, C.E. Devine, and S. Heinemann. 1974. Characterization of a unique muscle cell line. I. Cell Biol. 61: $398-413$.

Sen, R. and D. Baltimore. 1986. Multiple factors interact with the immunoglobulin enhancer sequences. Cell 46: 705716.

Sternberg, E.A., G. Spizz, W.M. Perry, D. Vizard, T. Weil, and E.N. Olson. 1988. Identification of upstream and intragenic regulatory elements that confer cell-type-restricted and differentiation specific expression on the muscle creatine kinase gene. Mol. Cell. Biol. 8: 2896-2909.

Sternberg, E., G. Spizz, M.E. Perry, and E.N. Olson. 1989. A rasdependent pathway abolishes activity of a muscle-specific enhancer upstream from the muscle-creatine kinase gene. Mol. Cell. Biol. 9: 594-601.

Tapscott, S.J., R.L. Davis, M.J. Thayer, P.-F. Cheng, H. Weintraub, and A.B. Lassar. 1988. MyoD1: A nuclear phosphoprotein requiring a myc homology region to convert fibroblasts to myoblasts. Science 242: 405-411.

Thayer, M.J., S.J. Tapscott, R.L. Davis, W.E. Wright, A.B. Lassar, and H. Weintraub. 1989. Positive autoregulation of the myogenic determination gene MyoD1. Cell 58: 241248.

Thisse, B., C. Stoetzel, C. Gorostiza-Thisse, and F. PerrinSchmitt. 1988. Sequence of the twist gene and nuclear localization of its protein in endomesodermal cells of early Drosophila embryos. EMBO I. 7: 2175-2183.

Villares, R. and C.V. Cabrera. 1987. The acheate-scute gene complex of D. melanogaster: Conserved domains in a subset of genes required for neurogenesis and their homology to myc. Cell 50: 415-424.

Wang, Y., H.-P. Xu, X.-M. Wang, M. Ballivet, and J. Schmidt. 1988. A cell type-specific enhancer drives expression of the chick muscle acetylcholine receptor $\alpha$-subunit gene. Neuron 1: $527-534$.

Weintraub, H., S.J. Tapscott, R.L. Davis, M.J. Thayer, M.A. Adam, A.B. Lassar, and A.D. Miller. 1989. Activation of muscle specific genes in pigment, nerve, fat, liver and fibroblast cell lines by forced expression of MyoD. Proc. Natl. Acad. Sci. 86: 5434-5438

Wright, W.E., D.A. Sassoon, and V.K. Lin. 1989. Myogenin, a factor regulating myogenesis, has a domain homologous to MyoD1. Cell 56: 607-617.

Yaffe, D. and O. Saxel. 1977. Serial passaging and differentiation of myogenic cells isolated from dystrophic mouse muscle. Nature 270: 725-727.

Yutzey, K.E., R.L. Kline, and S.F. Konieczny. 1989. An internal regulatory element controls troponin I gene expression. Mol. Cell. Biol. 9: 1397-1405. 


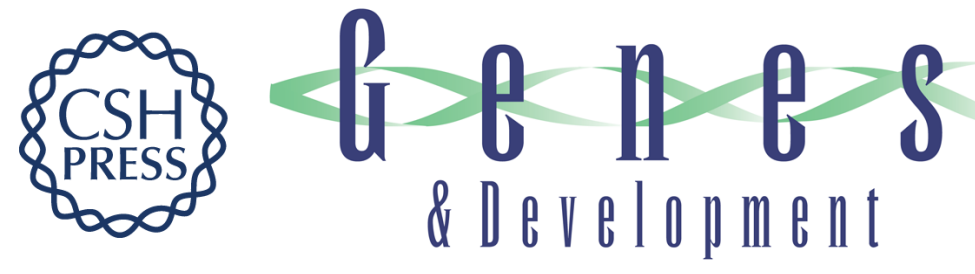

\section{Myogenin resides in the nucleus and acquires high affinity for a conserved enhancer element on heterodimerization.}

$\mathrm{T} \mathrm{J}$ Brennan and E N Olson

Genes Dev. 1990, 4:

Access the most recent version at doi:10.1101/gad.4.4.582

References This article cites 50 articles, 24 of which can be accessed free at: http://genesdev.cshlp.org/content/4/4/582.full.html\#ref-list-1

License

Email Alerting

Service

Receive free email alerts when new articles cite this article - sign up in the box at the top right corner of the article or click here.

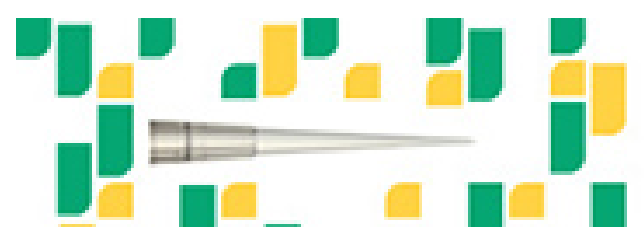

Focused on your science. 